\title{
Hama dan Penyakit Tanaman Poh-pohan (Pilea trinervia) di Kebun Petani di Bogor
}

\section{Pest and Diseases of Poh-pohan (Pilea trinervia) in Bogor}

\author{
Adiyantara Gumilang ${ }^{1}$, Hermanu Triwidodo ${ }^{1}$, Suryo Wiyono ${ }^{1,2^{*}}$
}

${ }^{1}$ Departemen Proteksi Tanaman Fakultas Pertanian Institut Pertanian Bogor, Jl Meranti Darmaga, Bogor, Indonesia ${ }^{2}$ Pusat Kajian Hortikultura Tropika Institut Pertanian Bogor, Jl Raya Pajajaran Baranangsiang, Bogor 16144, Indonesia

Diterima 21 Desember 2017/Disetujui 30 Januari 2018

\begin{abstract}
Poh-pohan (Pilea trinervia) is one of important indigenous vegetables. Pests and diseases on poh-pohan have not been studied. The aims of this research were to study pests and diseases of poh-pohan, management of pests and diseases, and agronomical practices in Bogor. Methods used in the study were Interview using structured questionnaire on 20 farmers, feld observation at two locations and laboratory identification. Symptoms of pest attack were found on leaf such as shot hole, leaf cut, and leaf speck. Pest of poh-pohan were worm larvae family Noctuidae, grasshopper family Acrididae, and leafhopper family Cicadellidae. Diseases of pilea were basal stem rot caused by Rhizoctonia solani Kuhn, leaf spot caused by Phyllosticta sp, antrachnose caused by Colletotrichum sp. There was no specific measures to control plant pests and diseases. Pilea was cultivated by in agroforestry system under pinus and damar stand.
\end{abstract}

Key words: agroforestry, attack symptoms of insect, indigenous vegetables, pests and diseases, poh-pohan.

\section{ABSTRAK}

Poh-pohan (Pilea trinervia) merupakan salah satu tanaman sayuran indigenous yang penting. Permasalahan hama dan penyakit di poh-pohan belum pernah diteliti. Penelitian ini bertujuan mengetahui jenis hama dan penyakit pada tanaman poh-pohan, pengelolaan hama dan penyakit, dan teknik budidaya yang dilakukan di dua lokasi budidaya poh-pohan di wilayah Kabupaten Bogor. Metode yang digunakan yaitu wawancara terhadap 20 petani, pengamatan lapangan di dua lokasi berbeda dengan mengambil 10 tanaman contoh secara diagonal dengan total 20 lahan dalam satu kali pengamatan, identifikasi, pengambilan sampel hama dan penyakit pada tanaman contoh, koleksi dan analisis data. Individu hama tidak ditemukan pada tanaman contoh. Gejala serangan hama yang ditemukan yaitu daun berlubang disebabkan oleh serangga dari famili Noctuidae, gerigitan pada daun disebabkan oleh famili Acrididae, dan bintik putih pada daun disebabkan oleh famili Cicadellidae. Penyakit yang ditemukan adalah busuk pangkal batang yang disebabkan oleh Rhizoctonia solani Kuhn. Bercak daun disebabkan oleh Phyllosticta sp. Antraknosa disebabkan oleh Colletotrichum sp. Pengendalian hama dan penyakit tidak dilakukan secara khusus. Teknik budidaya poh-pohan menggunakan sistem wanatani di bawah tegakan pohon damar dan pinus.

Kata kunci : gejala serangan hama, hama dan penyakit, poh-pohan, sayuran indigenous, wanatani.

\section{PENDAHULUAN}

Poh-pohan (Pilea trinervia) merupakan salah satu jenis tanaman sayuran indigenous yang penting di Jawa Barat. Poh-pohan dikonsumsi sebagai sayur segar. Pohpohan ditemukan di hutan alam sebagai tumbuhan liar, dan dalam skala kecil dibudidayakan. Poh-pohan merupakan salah satu sayuran indigenous, yaitu tanaman merupakan suatu tanaman yang dibudidayakan di daerah tertentu

* Penulis untuk korespondensi. e-mail: suryowiyono269@gmail.com
(Duriat et al. 1999). Poh-pohan merupakan sayuran yang diketahui mengandung antioksidan yang dapat menangkap munculnya radikal bebas. Senyawa fenol, asam askorbat, $\beta$-karoten, $\alpha$ - tofokerol merupakan sumber dari antioksidan (Desminarti, 2001). Menurut Dwiyani (2008), poh-pohan dikonsumsi dalam keadaan segar oleh Suku Sunda. Sayuran segar memiliki vitamin dan kandungan serat lebih besar dibandingkan dengan sayuran yang sudah dimasak.

Hama dan penyakit pada tanaman merupakan salah satu faktor yang dapat mengurangi produktivitas dari suatu tanaman budidaya. Sayuran indigenous berpotensi dikembangkan dalam skala lebih luas. Oleh karena itu, 
hama dan penyakit perlu diketahui untuk pengendalian hama penyakit di masa mendatang. Hingga saat ini belum ada penelitian mengenai hama dan penyakit poh-pohan. Penelitian ini bertujuan mengetahui jenis hama dan penyakit poh-pohan, pengelolaan hama dan penyakit, dan teknik budidaya poh-pohan di Kabupaten Bogor.

\section{BAHAN DAN METODE}

\section{Waktu dan Tempat Penelitian}

Penelitian dilakukan di Kampung Bobojong dan Calobak, Desa Taman Sari, Kecamatan Taman Sari, Kabupaten Bogor. Identifikasi penyakit dilakukan di Klinik Tanaman dan Laboratorium Mikologi Tumbuhan, Departemen Proteksi Tanaman, Fakultas Pertanian IPB. Identifikasi hama dilakukan di Laboratorium Biosistematika Serangga Departemen Proteksi Tanaman, Fakultas Pertanian IPB dari bulan November 2014 hingga Februari 2015.

\section{Metode}

Penentuan lahan dilakukan setelah pemilihan lahan contoh. Lahan contoh yang dipilih berjumlah 20 lahan terbagi di dua Kampung Bobojong dan Calobak. Wawancara dilakukan secara langsung kepada 20 petani yang dipilih secara acak terbagi di Kampung Bobojong dan Calobak. Wawancara dilakukan untuk mendapatkan informasi tentang permasalahan hama dan penyakit pada poh-pohan, pengendalian hama penyakit pada poh-pohan, dan teknik budidaya poh-pohan. Wawancara petani pohpohan menggunakan blanko wawancara petani dari Klinik Tanaman IPB.

\section{Pengamatan Lapangan}

Pengamatan dilakukan sekali dengan mengambil 20 petak contoh yang terdapat di Kampung Calobak dan Bobojong. Setiap petak contoh tanaman poh-pohan diambil 5 titik pengamatan dimana dalam satu titik terdiri dari 2 tanaman dan diberi jarak 5 tanaman berikutnya. Lahan pengamatan yang digunakan adalah milik petani poh-pohan yang sudah diwawancarai.

Bagian tanaman yang diamati adalah daun, batang, dan keseluruhan tanaman. Penghitungan insidensi hama atau penyakit di lapangan merupakan persentase jumlah tanaman yang terserang penyakit terhadap jumlah seluruh tanaman yang digunakan setiap petak contoh. Adapun rumus perhitungan persentase insiden atau kejadian penyakit sebagai berikut :

$$
I P(\%)=\frac{J T}{J K} \times 100 \%
$$

Keterangan : IP $=$ Insiden atau kejadian penyakit $(\%)$, $\mathrm{JT}=$ Jumlah tanaman terserang, JK $=$ Jumlah keseluruhan tanaman.
Keparahan penyakit menggunakan rumus:

$$
\text { Keparahan penyakit }(\%)=\frac{\Sigma(\text { nivi })}{\mathrm{NV}} \times 100 \%
$$

Keterangan : ni = jumlah tanaman dengan skor ke-i, $\mathrm{vi}=$ nilai skor penyakit dari, $\mathrm{N}=$ jumlah tanaman yang diamati, $\mathrm{V}=$ skor tertinggi

Penilaian penyakit bercak daun phyllosticta pada tanaman poh-pohan dilakukan dengan menggunakan penilaian keparahan seperti Tabel 1 sedangkan penilaian keparahan penyakit antraknosa pada tanaman poh-pohan Tabel 2.

\section{Identifikasi Hama dan Penyakit}

Sampel hama dan penyakit diambil dari bagian tanaman contoh untuk diidentifikasi di laboratorium. Sampel hama disimpan di dalam botol plastik dan kantong plastik. Bagian tanaman yang bergejala penyakit disimpan di dalam kantong plastik. Baik sampel hama maupun penyakit dibawa ke laboratorium. Identifikasi serangga menggunakan dengan kunci identifikasi Borror et al. (1992). Identifikasi penyakit dilakukan dengan menggunakan buku identifikasi Barnett dan Hunter (1998) dan Watanabe (2002).

\section{Analisis data}

Data insidensi hama, insidensi dan keparahan penyakit

Tabel 1. Penilaian keparahan bercak daun/phyllosticta pada poh-pohan

\begin{tabular}{cc}
\hline Skor & Keparahan Serangan \\
\hline 0 & tidak ada serangan \\
1 & Serangan $1 \leq \mathrm{x}<25$ \\
2 & Serangan $25 \leq \mathrm{x}<50$ \\
3 & Serangan $50 \leq \mathrm{x}<75$ \\
4 & Serangan $\mathrm{x} \geq 75$ \\
\hline
\end{tabular}

Tabel 2. Penilaian keparahan penyakit antraknosa pada pohpohan

\begin{tabular}{cc}
\hline Skor & Keparahan serangan \\
\hline 0 & tidak ada serangan \\
1 & Serangan $1 \leq \mathrm{x}<20$ \\
2 & Serangan $20 \leq \mathrm{x}<50$ \\
3 & Serangan $40 \leq \mathrm{x}<60$ \\
4 & Serangan $60 \leq \mathrm{x}<80$ \\
5 & Serangan $\mathrm{x} \geq 80$ \\
\hline
\end{tabular}


tanaman poh-pohan yang diperoleh dari pengamatan langsung di lapangan ditampilkan dan diolah menggunakan Microsoft Excel 2013 sehingga diperoleh nila rata-rata dan simpangan baku.

\section{HASIL DAN PEMBAHASAN}

Sejarah, Kondisi Umum Pertanaman dan Teknik Budidaya Poh-pohan

Lokasi budidaya poh-pohan di Kampung Bobojong dan Calobak, Desa Taman Sari, Kecamatan Taman Sari, Kabupaten Bogor berada dalam kawasan Taman Nasional Gunung Halimun Salak (TNGHS) (BTNGHS 2012). Kondisi umum budidaya poh-pohan di Kampung Calobak dan Bobojong memiliki kondisi yang hampir sama dilihat dari kondisi lingkungan sekitar dan teknik budidaya yang dilakukan. Budidaya poh-pohan berada di bawah tegakan pohon pinus (Pinus merkusii), damar (Agathis damara), dan kaliandra (Calliandra callothyrsus dan C. tetragoma).

Petani poh-pohan di kedua kampung melakukan budidaya poh-pohan pada tanah dalam kawasan Taman Nasional Gunung Halimun Salak (TNGHS) dengan system agroforestry atau wanatani. Jadi petani poh-pohan merupakan penggarap pada lahan yang secara legal dalam otoritas BTNGHS. Beberapa aspek budidaya poh-pohan dan teknik budidaya disajikan di dalam Tabel 3 .

Teknik budidaya yang digunakan oleh sejumlah petani poh-pohan di kedua kampung menggunakan sistem wanatani atau agroforestry. Budidaya poh-pohan di bawah tegakan damar dan pinus sudah dilakukan semenjak tahun 1991. Petani poh-pohan memanfaatkan area di bawah tegakan pohon damar, pinus, dan kaliandra untuk budidaya poh-pohan.

Pada awalnya petani poh-pohan di kedua kampung belum mempunyai izin resmi untuk memanfaatkan lahan kosong dibawah tegakan pinus dan damar, namun pada

Tabel 3. Beberapa aspek budidaya poh-pohan di dua lokasi pengamatan

\begin{tabular}{lcc}
\hline \multirow{2}{*}{ Informasi Budidaya } & \multicolumn{2}{c}{ Budidaya poh-pohan } \\
\cline { 2 - 3 } Dataran Lokasi & Calobak & Bobojong \\
\hline Ketinggian (m dpl) & $743-821$ & Tinggi \\
Luas (m2) & $500-2500$ & $250-922$ \\
Cara tanam & Wanatani & wanatani \\
Jarak tanam (cm) & $5 \times 5,10-20 \times 10-205 \times 5,10-20 \times 10-20$ \\
Pengendalian gulma & manual & manual \\
Kondisi lahan & terawat & terawat \\
Waktu panen (bulan) & $2-J a n$ & 1 \\
Produksi hasil panen & $3000-25000$ & $300-20000$ \\
(ikat) & & \\
\hline
\end{tabular}

tahun 2002 kegiatan wanatani di kedua kampung mempunyai kekuatan hukum sehingga terbentuk Kelompok Tani Hutan Mekarsari (Priana, 2004). Keterpaduan antara masyarakat sekitar hutan dan Perum Perhutani melalui Program Pengelolaan Sumberdaya Hutan Bersama Masyarakat (PHBM) bertujuan untuk mewujudkan pengelolaan sumberdaya hutan berkelanjutan bersama masyarakat. Naungan berpengaruh terhadap diameter batang, tinggi tanaman, panjang dan lebar daun poh-pohan (Ekawati et al. 2010).

Peran agroekologi wanatani mempunyai peranan dalam hubungan antar sesama komponen seperti: keberlanjutan, keanekearagaman, dan ekonomi sehingga terbentuknya sebuah sistem keterpaduan di dalamnya (Wojtkowski, 2002). Menurut Singh (1995) wanatani mempunyai sejumlah kelebihan diantaranya pencegahan erosi, siklus nutrisi, fiksasi nitrogen, penambahan bahan organik dan perubahan iklim mikro.

Petani poh-pohan mendapatkan bibit dari budidaya poh-pohan sebelumnya dengan cara memotong bagian batang kemudian ditanam di petakan. Setek bibit diperoleh dari sesama petani poh-pohan dan diperbanyak sendiri. Menurut Mahyar (1994) tanaman poh-pohan termasuk kedalam Famili Urticacae. Poh-pohan tumbuh tegak herba monoecious atau dioceous dapat mencapai ketinggian $2 \mathrm{~m}$. Ukuran daun 6-20 $\mathrm{cm} \times 2-10 \mathrm{~cm}$ untuk $P$. trinervia dan $P$. glabberima $6-25 \mathrm{~cm} \times 2-8 \mathrm{~cm}$. Bentuk daun meruncing dan panjang petiol mencapai $1-10 \mathrm{~cm}$. Terdapat dua spesies utama yang umum diketahui yaitu $P$. trinervia dan $P$. glabberima (Blume). Poh-pohan memiliki bunga jantan atau betina dan warna bunga putih kehijau-hijauan.

Poh-pohan dapat ditemukan di hutan, perbatasan hutan, dan sekitar aliran air dengan ketinggian 500-2500 mdpl. Perbanyakan poh-pohan dapat dilakukan menggunakan pemotongan cabang lateral dan benih. Namun pengguanan benih harus terlebih dahulu disemai di dalam tray karena ukuran benih poh-pohan sangat kecil. Petani poh-pohan di kedua kampung umumnya menggunakan jarak tanam 5x20 $\mathrm{cm}$. Petani poh-pohan menggunakan jarak tanam dengan kerapatan tinggi bertujuan untuk mendapatkan hasil panen lebih tinggi. Alasan utama kerapatan jarak tanam adalah tambahan pendapatan bagi para petani poh-pohan untuk menutupi modal yang telah dikeluarkan untuk keperluan budidaya poh-pohan.

Pengendalian gulma yang dilakukan petani pohpohan di kedua kampung tersebut sama. Pengendalian dilakukan secara manual menggunakan alat kored. Waktu pengendalian gulma dilakukan setiap 1 bulan atau setelah panen. Pengendalian secara kimia menggunakan herbisida tidak pernah dilakukan oleh petani poh-pohan di kedua kampung tersebut.

Pemanenan poh-pohan di kedua kampung tidak jauh berbeda. Petani poh-pohan memerlukan waktu 1-2 bulan dalam satu kali panen, jika bibit poh-pohan yang digunakan sudah lebih dari 3-4 bulan. Penanaman awal menggunakan bibit poh-pohan memerlukan waktu sekitar 3-4 bulan. Petani poh-pohan di kedua kampung membuat petakan persegi panjang berukuran berkisar 5-6 m x 5-7 m . Hasil 
panen yang diperoleh dikumpulkan dalam ikatan dan dijual kepada tengkulak. Penjualan poh-pohan dari petani pohpohan dibatasi 2000-3000 ikat oleh tengkulak. Setiap ikatan poh-pohan terdiri dari 8-10 batang dengan harga jual Rp 800 per ikat kecil, sedangkan poh-pohan dalam ikatan besar merupakan gabungan dari 10 ikatan kecil yang berjumlah 10 ikat dengan harga jual Rp 7500-8500 per ikat besar.

Jenis pupuk yang digunakan dalam budidaya pohpohan oleh petani adalah pupuk kandang ayam, urea, dan NPK. Pupuk kandang ayam merupakan pupuk yang berasal dari kotoran ayam yang telah dicampur oleh sekam padi. Petani poh-pohan memperoleh pupuk kandang ayam dengan membeli di peternakan ayam yang berada di sekitar kampung. Pupuk kandang ayam yang diperoleh petani disimpan dalam karung.

Pemupukan pupuk kandang ayam dilakukan diawal tanam. Waktu pemupukan untuk kandang ayam disesuaikan dengan ketersediaan pupuk kandang ayam di peternakan. Pada umumnya pemupukan menggunakan pupuk kandang ayam dilakukan 1-2 setiap bulannya atau setelah panen. Pemupukan pupuk kandang ayam di Kampung Bobojong berkisar 1-5 karung/petak sedangkan di Kampung Calobak berkisar 1/2-1 karung/petak.

Pemupukan urea dan NPK umumnya dilakukan secara berselang dengan frekuensi 2-6 bulan, namun penggunaan urea dan NPK merupakan pilihan lain petani poh-pohan jika ketersediaan pupuk kandang ayam tidak cukup. Pemupukan urea di Kampung Calobak 1/2-3/4 kg/petak tidak jauh berbeda dengan pemberian pemupukan yang diberikan petani poh-pohan di Kampung Bobojong sekitar 1/2-1 kg/ petak. Pemupukan NPK hanya dilakukan oleh petani dari Kampung Calobak.

\section{Hama Tanaman Poh-pohan}

Tabel 4 menunjukkan masalah hama poh-pohan berdasarkan hasil wawancara petani poh-pohan di kedua kampung. Gangguan hama dalam budidaya pertanian merupakan permasalahan umum. Hama babi hutan (Sus scrofa) dan kera (Macaca spp.) merupakan masalah hama yang dihadapi oleh petani poh-pohan dalam budidaya pohpohan karena lokasi budidaya poh-pohan yang berada di kawasan hutan dan merupakan habitat bagi babi hutan dan kera. Jenis kerusakan yang disebabkan oleh babi hutan

Tabel 4. Hama poh-pohan di kedua kampung

\begin{tabular}{|c|c|c|c|}
\hline \multirow{2}{*}{ Jenis Hama } & \multicolumn{3}{|c|}{ Tingkat Kepentingan } \\
\hline & Calobak & Bobojong & Bagian diserang \\
\hline Babi Hutan & +++ & +++ & petakan \\
\hline Kera & ++ & ++ & batang \\
\hline Ulat & ++ & ++ & daun \\
\hline Belalang & ++ & ++ & daun \\
\hline
\end{tabular}

adalah kerusakan pada petakan poh-pohan. Kerusakan mengakibatkan petani poh-pohan harus menanam ulang kembali poh-pohan. Kerusakan yang diakibatkan kera dengan mematahkan bagian batang sehingga mengurangi jumlah hasil bagian daun yang akan dipanen. Babi hutan dan kera termasuk ke dalam hama dalam pertanian. Kerusakan yang ditimbulkan oleh babi hutan dapat merusak pada fase pembibitan sedangkan kera merusak dengan cara memakan buah, akar dan batang (Kalshoven 1981). Walaupun termasuk hama penting menurut petani, hama babi hutan dan kera tidak dapat dipastikan keberadaannya selama pengamatan.

Gejala serangan hama ditemukan pada tanaman contoh di kedua lokasi adalah daun berlubang, daun terpotong, dan bintik putih. Belalang dari famili Acrididae merupakan penyebab daun berlubang, larva ulat dari famili Noctuidae untuk daun terpotong, dan wereng daun Cicadellidae untuk bintik putih. Serangga-serangga hama terrsebut tidak dijumpai pada tanaman contoh.

Tabel 5 menunjukkan tingkat serangan hama secara umum di Calobak lebih besar dibandingkan dengan Bobojong. Hal ini karena kebun poh-pohan di Calobak berumur lebih lama (1 tahun) dibanding Bobojong (6 bulan). Kebun yang telah tua terjadi akumulasi hama/ penyakit hingga suatu waktu serangan hama besar dan harus dilakukan rotasi tanaman.

Keberadaan populasi serangga dapat dipengaruhi oleh kelimpahan pakan, lingkungan biotik dan abiotik. Sementara itu, pengamatan berlangsung saat musim hujan sehingga diduga keberadaan hama dipengaruhi dari curah hujan, cahaya, suhu, dan kelembaban saat pengamatan berlangsung. Menurut Henley et al. (2013), hama- hama yang ditemukan di Pilea sp. antara lain kutu - kutuan, ulat jengkal, thrips, tungau, keong, dan siput.

\section{Penyakit Tanaman Poh-pohan}

Permasalahan penyakit dalam budidaya tanaman merupakan hambatan dalam budidaya. Pengetahuan mengenai penyakit-penyakit merupakan dasar pengendalian untuk pencegahan dini dan strategi pengendalian penyakit dalam budidaya. Tabel 6 menyajikan jenis-jenis penyakit yang menyerang tanaman poh-pohan berdasarkan wawancara petani poh-pohan.

Petani poh-pohan memberi nama penyakit berdasarkan gejala yang muncul misalnya layu disebut lodoh, gejala bercak daun disebut poken, dan gejala bercak daun hitam disebut budug. Petani poh-pohan masih menggangap jenisjenis penyakit yang muncul di pertanaman masih dalam kategori sedang.

Penyakit yang disebut lodoh oleh petani setelah dikonfirmasi dengan pengambilan sampel dan pemeriksaan laboratorium, adalah penyakit busuk batang yang disebabkan Rhizoctonia solani. Busuk pangkal batang atau lodoh hanya ditemukan di Kampung Bobojong. Busuk pangkal batang mempunyai gejala dan tanda pada pangkal batang berwarna hitam dan terlihat miselium berwarna putih. Pengamatan secara mikroskopik dengan mengambil bagian batang 
Tabel 5 Insidensi serangan hama poh-pohan berdasarkan gejala

\begin{tabular}{lccc}
\hline \multirow{2}{*}{ Desa } & \multicolumn{3}{c}{ Tanaman bergejala (\%) } \\
\cline { 2 - 4 } & Daun Berlubang & Daun terpotong & Daun bintik putih \\
\hline Calobak & $78.00 \pm 20.43$ & $85.00 \pm 12.69$ & $87.00 \pm 20.57$ \\
Bobojong & $69.00 \pm 28.06$ & $69.00 \pm 20.78$ & $32.00 \pm 31.19$ \\
\hline
\end{tabular}

Tabel 6. Penyakit-penyakit poh-pohan menurut petani

\begin{tabular}{lccc}
\hline \multirow{2}{*}{ Nama lokal penyakit } & \multicolumn{3}{c}{ Tingkat Kepentingan } \\
\cline { 2 - 4 } & Calobak & Bobojong & Bagian diserang \\
\hline Lodoh & ++ & ++ & Batang \\
Poken & ++ & ++ & Daun \\
Budug & ++ & ++ & Batang, Daun \\
Pirang & ++ & ++ & Daun \\
\hline
\end{tabular}

Keterangan: $+=$ Tidak bermasalah, $++=$ sedang, $+++=$ Bermasalah,$++++=$ Sangat bermasalah

terinfeksi, terlihat hifa-hifa hialin dan percabangan hifa yang bersudut siku siku. Penyakit ini menyebabkan tanaman layu hingga tanaman mati sehingga mengganggu hasil produktivitas tanaman budidaya. Cendawan-cendawan tular tanah umumnya merupakan patogen penyebab munculnya penyakit busuk pangkal batang dan busuk akar.

Kisaran inang $R$. solani sangat luas dan dikenal sebagai cendawan tular tanah. Gejala yang disebabkan oleh patogen antara lain pangkal batang, busuk akar dan hawar daun. Sementara itu, penyakit ini dikenal sebagai penyakit di pembibitan. R.solani dapat bertahan hidup selama bertahuntahun di tanaman dan tanah. Bercak daun ditemukan di kedua kampung. Permukaan daun terlihat bercak coklat-keemasan dan pinggiran bercak terdapat lesio kuning berdasarkan gejala pengamatan pada tanaman contoh di kedua kampung. Petani poh-pohan di kedua kampung menyebut bercak daun ini pirang. Pemberian istilah disesuaikan berdasarkan gejala karena daun terlihat menjadi coklat keemasan. Setelah dilakukan pengecekan lapangan penyakit pirang merupakan penyakit bercak daun. Identifikasi selanjutnya bercak daun tersebut disebabkan oleh cendawan Phyllosticta sp.

Setelah dilakukan pemeriksaaan lapangan dan laboratorium, penyakit yang disebut petani sebagai 'budug' merupakan penyakit antraknosa. Penyakit ini disebabkan oleh Colletotrichum sp. Penyakit ini hanya ditemukan di Kampung Bobojong. Antraknosa yang ditemukan di Bobojong menginfeksi pada bagian batang dan daun pohpohan. Bagian daun poh-pohan terinfeksi berwarna hitam dan menyebabkan nekrotik. Pada bagian batang dan daun terlihat seta-seta hitam disekitar batang. Konidia cendawan hialin dan berbentuk bulan sabit, sedangkan seta berwarna gelap. Penyakit poh-pohan yang ditemukan di kebun poh-pohan rakyat di Bogor ada tiga jenis yaitu busuk batang yang disebabkan Rhizoctonia solani, bercak daun yang disebabkan oleh Phyllosticta sp., dan antraknosa yang disebabkan oleh Colletotrichum sp. Insidensi dan keparahan penyakit tersebut ditampilkan pada Tabel 7 dan 8 . Kejadian penyakit busuk pangkal batang hanya ditemukan di Kampung Calobak. Kejadian penyakit busuk pangkal batang di Calobak mencapai 46\%. Busuk pangkal batang hanya ditemukan di setiap lahan milik petani poh-pohan Kampung Calobak.

Kebun poh-pohan yang diamati mempunyai insidensi bercak daun yang tinggi dan adanya penyakit antraknosa. Kedua penyakit ini berkaitan dengan curah hujan yang tinggi, karena baik Phyllosticta maupun Colletotrichum mempunyai cara utama ppenyebaran spora dengan percikan air ( Waller 1992; Wikee et al 2012). Penyakit busuk pangkal batang yang disebabkan Rhizoctonia solani merupakan penyakit yang paling merugikan, karena bisa mematikan tanaman. Kadar air tanah yang tinggi serta pertanaman yang terus menerus berkaitan dengan tingginya serangan penyakit ini. Cendawan $R$. solani merupakan cendawan soilborne, yang akan mengalami akumulasi inokulum pada pertanaman monokultur yang terus menerus (Specht dan Leach 1987).

Insidensi dan keparahan penyakit di Calobak jauh lebih tinggi dibanding kebun di Bobojong. Hal ini karena kebun di Calobak lebih tua. Semakin tua umur kebun tingkat serangan penyakit lebih tinggi karena terjadi akumulasi inokulum. Budidaya poh-pohan oleh petani hutan di Bogor bisa digolongkan budidaya semi intensif yang ditunjukkan dengan sangat rendahnya penggunaan pupuk buatan, dan tidak digunakannya pestisida. Walaupun demikian pada kebun semi intensif tersebut sudah menghadapi serangan hama dan penyakit. Serangan hama dan penyakit cenderung tinggi pada poh-pohan budidaya. Agroekosistem kebun poh-pohan mempunyai sifat yang berbeda dengan ekosistem aslinya yaitu poh-pohan liar. Perbedaan utamanya adalah pada kebun poh-pohan mempunyai jarak tanam yang 
Tabel 7. Insidensi beberapa penyakit tanaman poh-pohan

\begin{tabular}{lccc}
\hline \multirow{2}{*}{ Desa } & \multicolumn{3}{c}{ Kejadian penyakit (\%) } \\
\cline { 2 - 4 } & Busuk pangkal batang $($ R. solani $)$ & Bercak daun $($ Phyllosticta sp). & Antraknosa (Colletotrichum sp.) \\
\hline Calobak & $46.00 \pm 17.76$ & $96.00 \pm 8.43$ & $0.00 \pm 0.00$ \\
Bobojong & $0.00 \pm 0.00$ & $39.00 \pm 29.98$ & $1.00 \pm 3.16$ \\
\hline
\end{tabular}

Tabel 8. Keparahan beberapa penyakit poh-pohan

\begin{tabular}{lccc}
\hline \multirow{2}{*}{ Desa } & \multicolumn{3}{c}{ Keparahan penyakit (\%) } \\
\cline { 2 - 4 } & Busuk pangkal batang (R. solani) & Bercak daun (Phyllosticta sp.) & Antraknosa (Colletotrichum sp.) \\
\hline Calobak & $46.00 \pm 17.76$ & $24.00 \pm 2.10$ & $0.00 \pm 0.00$ \\
Bobojong & $0.00 \pm 0.00$ & $10.25 \pm 8.37$ & $0.20 \pm 0.63$ \\
\hline
\end{tabular}

lebih rapat, keragaman spesies tanaman yang lebih rendah, ada pemupukan lebih intensif. Strategi pengendalian yang tepat perlu di kembangkan untuk penyakit busuk batang, bercak daun dan antraknosa tepat apabila poh-pohan akan dikembangkan dalam skala yang luas dan lebih intensif.

\section{Pengendalian Hama dan Penyakit Poh-pohan}

Pengendalian hama dan penyakit tidak dilakukan secara khusus oleh petani poh-pohan di kedua kampung. Keberadaan hama pada tanaman poh-pohan hanya didiamkan oleh petani poh-pohan karena petani poh-pohan menggangap kerugian belum tinggi. Petani poh-pohan melakukan pengendalian penyakit dengan membuang bagian daun yang terinfeksi jika poh-pohan sudah mati. Namun beberapa petani poh-pohan tidak membuang pohpohan yang sakit dan membiarkannya di lahan, sehingga dapat menjadi sumber inokulum.

\section{KESIMPULAN}

Teknik budidaya poh-pohan di Kecamatan Tamansari Kabupaten Bogor dilakukan dengan menggunakan sistem wanatani di bawah tegakan damar, pinus, dan kaliandra. Hama yang menyerang poh-pohan yaitu belalang famili Acrididae, larva ulat Noctuidae, dan wereng daun Cicadellidae. Penyakit yang menjadi masalah pada poh-pohan di lokasi pengamatan yaitu busuk pangkal batang disebabkan oleh Rhizoctonia solani, bercak daun disebabkan oleh Phyllosticta sp. dan antraknosa disebabkan oleh Colletotrichum sp. Tidak ada pengendalian khusus hama dan penyakit poh-pohan di kebun yang diamati.

\section{DAFTAR PUSTAKA}

Barnet, H.L., B.B. Hunter. 1988. Ilustrated Genera of Imperfect Fungi. Ed ke-4. Minnesota (US). APS Press.
Borror, D.J., C.A. Triplehorn, N.F. Johnson. 1992. An introduction to the study of insects / Philadelphia: Saunders College Pub., 875 p.

[BTNGHS] Balai Taman Nasional Gunung Halimun Salak. 2013. Keanekaragaman hayati. Balai Taman Nasional Gunung Halimun Salak. http://halimunsalak.org/ tentang-kami/keanekaragaman-hayati/ $\quad\left[\begin{array}{ll}7 & \text { Maret }\end{array}\right.$ 2015].

Desminarti, S. 2001. Kajian serat pangan dan antioksidan alam beberapa jenis sayuran serta daya serap dan resistensi antioksidan pada tikus percobaan. Tesis. Institut Pertanian Bogor. Bogor.

Duriat, S.A., A. Asgar, Z. Abidin. 1999. Indigenous vegetables in Indonesia: Their conservation and utilization. Dalam Engle, L.M., Altoveros, N.C., editor. Collection Conservations and Utilization of Indigenous Vegetables. Proceedings of a Workshop AVDRC; 1999 Agustus 16-19; Shanhua. Tainan (TW): Asian Vegetable Research and Development Center and Asian Development Bank. hlm 29-42.

Dwiyani, R. 2008. Identifikasi golongan senyawa antioksidan pada daun poh-pohan (Pilea trinervia). Skripsi. Institut Pertanian Bogor. Bogor.

Ekawati, R., D.A. Susila, G.J. Kartika. 2010. Pengaruh naungan tegakan pohon terhadap pertumbuhan dan produktivitas beberapa tanaman sayuran indigenous. $J$ Hort. 1ndones. (1): 46-52.

Henley, W.R., A.R. Chase, S.L. Osborne. 2013. Pilea production guide. Florida (US) : Central Florida Research and Education Center. http://mrec.ifas.ufl. edu/foliage/folnotes/pilea.htm [21 Maret 2015]. 
Kalshoven, L.G.E., (1981). The Pest of Crops in Indonesia. Revised and Translated By P.A. Van der laan. Jakarta: PT. Ichtiar Baru-Van Hoeve.

Mahyar, U.W. 1994. Pilea. Dalam J.S. Siesmonsa, K. Piluek. Editor. Plant Resources of South-East Asia No. 8; Vegetables. Prosea Foundation. hlm 225-226. Bogor.

Priana, A.M. 2004. Identifikasi faktor-faktor yang berhubungan dengan tingkat kemandirian petani dalam melakukan usaha agroforestri (kasus usaha agroforestri poh-pohan di hutan pinus dan damar desa taman sari kecamatan taman sari kabupaten bogor). Tesis. Institut Pertanian Bogor. Bogor.

Singh P. 1995. Land degradation - a global menace and its improvement through agroforestry. Dalam Sing, P., Pathak, P.S., Roy, M., editor. Agroforestry System for Sustainable Land Use. New Delhi (IN): Sciences Publisher. Hlm 4-20.

Specht, L.P., S.S. Leach. 1987. Effect of crop rotation on Rhizoctonia disease of potato. Plant Disease 71:433437.
Waller, J.M. 1992. Colletrotichum disease of perennial and other cash crops. Dalam: J.A. Bailey, M.J. Jeger, editor. Colleotrichum : Biology, Pathology and Control. Oxon (UK): CAB International. hlm 167185.

Watanabe, T. 1937. Pictorial Atlas of Soil and Seed Fungi: Morfologies of Cultured Fungi and Key to Species. Ed ke-2. Boca Raton (US): CRC Press.

Wojtkowski, A. 2002. Agroecological Perspectives in Agronomy, Forestry, and Agroforestry. Ed ke-1. (US): Science Publisher.

Wikee, S., D. Udayanga, P.W. Crous, E. Chukeatirote, H. Eric, C. McKenzie, A.H. Bahkali, D.I. Dai, K.D. Hyde. 2011. Phyllosticta - an overview of current status of species recognition. Fungal Diversity (2011) 51:43-61 